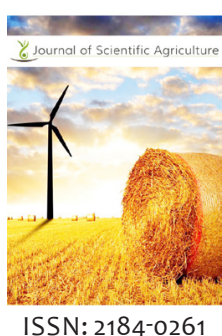

Received: April 06,2020 Accepted: May 07,2020 Published: May 14, 2020

*Corresponding Author: Akintobi O.S

Email: akintobiolanrewaju@ gmail.com

\section{Analysis of the challenges of small-scale farmers' access to labor in North Central Nigeria}

\author{
Akintobi 0.5* \\ Department of Agricultural Extension and Rural Sociology, University of Abuja, Nigeria
}

\begin{abstract}
The study analyzed the challenges experienced by small-scale farmers' in accessing human labor in North Central Nigeria. Multi-stage random sampling technique was used for sample selection while questionnaires were used for data collection. A total of 1,750 farmers were randomly interviewed. Data were analyzed using descriptive statistics and one-way factorial analysis of variance and mean separation was done at 5\% probability level. Result revealed small scale farmers perceived a lack of access to human labor for agricultural activities in the zone while mean separation showed Niger state has the highest access to labor while Abuja and Kwara states are the least state with access to labor. High cost of labor, lack of fund and scarcity of labor are the major challenges experienced by the farmers in accessing labor for agricultural production. Based on the findings, the research concluded that small scale farmers do not good access to labor while facing serious challenges which has resulted into increased cost of production for the small-scale farmers. The study recommends among others that combine hiring should be encouraged among farmers for the adoption of expensive labor saving technologies/implements.
\end{abstract}

KEYWORDS: Agricultural Production, labor accessibility, challenges, labor availability
Labor is one of the factors of production which involves family and non- family, labor includes those that are rated on daily or hourly basis. Labor is the group of productive service provided by human physical effort, skill, and mental power. It is the work input of people- not the people themselves [1]. It is the tool with which capital and managerial skills are used to extract profit from the land, labor input is usually measured in man- days or sometimes man-hours, which represent the input of work of an average man in a working day or hour, Efficiency of labor use as a production factor is expressed by the level of labor productivity which is the technical efficiency of human work utilized in creation of useful goods. According to Nmadul and Akinola [2], Labor plays important economic and social roles in any economy. It is one of the key factors of production as well as a source of livelihood to billions of people worldwide. Nigeria's agricultural production is highly labor intensive. Over $90 \%$ of non-mechanized production systems depend on human labor, and for mechanized production systems, between 50 and $60 \%$ of the tasks depend on human labor.

Furthermore, Nmadul and Akinola [2] emphasized that family labor constitutes over $76 \%$ of farm labor and human labor is about the only form of farm labor available to farmers and farmers contribute over $80 \%$ of total domestic agricultural output, it therefore means that human labor accounts for domestic food supplies in Nigeria. Therefore, the hope to continue to supply the food need of the ever-growing population anchors very auspiciously on human labor availability and productivity. Yeboah and Jayne [3] claimed human labor is about the only main source of labor accessible to small-holder farmers in Nigeria. Hired labor contributes $88.0 \%$ of the total labor use on farms thus emphasizing its importance in agricultural activities.

According to Nmadul and Akinola [2], Nigeria's food deficient situation has been worsened by declining farm productivity owing to inefficient production techniques, poor resource base and insufficient farm labor supply among others. Labor has been found to constitute a large proportion of cost in the food crop production process in Nigeria and its productivity has become increasingly low because farm households largely comprised fairly old people and very young children coupled with the use of crude implements which impede their ability to raise yield of food crops and income with subsequent reduction in poverty level. The sharp decline in labor supply for agricultural production in the country is attributed to a host of factors such as rural-urban migration, increase enrolment in school, increased employment opportunities accompanying

Copyright: $\odot$ The authors. This article is open access and licensed under the terms of the Creative Commons Attribution License (http://creativecommons.org/licenses/by/4.0/) which permits unrestricted, use, distribution and reproduction in any medium, or format for any purpose, even commercially provided the work is properly cited. Attribution - You must give appropriate credit, provide a link to the license, and indicate if changes were made. 
industrialization, urbanization as well as increased off farm employment. Because of the increased participation of labor in off-farm activities which culminated in scarcity of farm labor and rising labor wage rate, there is great fear that agricultural growth and development may be retarded and our whole effort of achieving self-sufficiency in food crop production would be a mirage [4].

Based on the above, this study will therefore analyze challenges of small-scale farmers' access to labor in North Central Nigeria.

While the specific objectives are to:

1. determine level of access to labor input in north central Nigeria

2. challenges of small-scale farmers access to labor input.

\section{The Hypothesis of the study states that}

$\mathrm{H}_{\mathrm{o}}$ : Small-scale farmers in north central Nigeria do not perceive the lack of access to labor input.

\section{MATERIALS AND METHOD}

The study was carried out in the north central zone of the Nigeria, it is one of the six geo-political zones in the country, the population of the study consists of all small-scale farmers in selected communities in the north central region of Nigeria. 5 states were randomly selected out of the 7 states in the zone.

Multi stage random sampling was used to select determine the sample size. In the first stage, three (3) agricultural zones was selected from each of the states while in the second stage six (6) agricultural extension blocks from each of the agricultural zones was randomly selected giving a total 18 blocks. In the third stage, 5 cells were randomly selected from each of the 18 agricultural extension blocks resulting in a total of 90 cells. Finally, in each of the 90 cells (fourth stage), 4 farmers were randomly selected and interviewed giving a total of 360 respondents from each of the states. In total 1,750 respondents from the five north central states was interviewed for this study.

Data collected was subjected to descriptive statistics while ANOVA was used to test the relationships that exist between the variables in the hypothesis.

\section{RESULT AND DISCUSSION}

\section{Socioeconomic Characteristics of Respondents}

From Table 1, the age status reveals $13.4 \%$ of the respondents are below 30 years of age, $26.4 \%$ are between the $31-40$ years age range, $28.3 \%$ of the respondents are between 41 to 50 years of age, while $14.5 \%$ of the respondents are aged between $50-60$ years of age and a meager $7.4 \%$ of the total respondents are above 60years. This report showed that small scale farmers in north central Nigeria are young and active adults and if proper inputs are set in place, they can produce more from their present production rate. This study correlate with the research of Akintobi et al. [5] which stated that most of the farmers in north central Nigeria are agile and in their productive ages who are active in arable crop production and have potential drive to sustain agricultural production for many years. The educational status reveals that $22.4 \%$ of the small-scale farmers had no formal education, $24.6 \%$ possess only primary school education, $32.3 \%$ of the farmers were educated up to the secondary level while $20.7 \%$ of the respondents had post-secondary education. This has shown that small scale farmers in North central Nigeria possess good educational level. These results imply that level of awareness and adoption of agricultural innovations among the farmers would be very high. Literate farmers are expected to be more innovative because of their ability to obtain and comprehend information more quickly and their ability to take more risk [6].

The years of farming experience accrued by the farmers shows that $23.4 \%$ of the respondents had less than 10 years of agricultural experience, $28.4 \%$ had between 11 and 20 years agricultural experience, $27.1 \%$ of the farmers have had between 21 to 30 years' experience in agricultural production, $16.4 \%$ have 31-40 years of experience while small scale farmers who had over 40 years agricultural experience were only $4.7 \%$. This result reveals small scale farmers in the study area have considerable years of farming experience. This is in line with Apata [7] who stated that farmers who have an experience of over ten years are no more novices in agricultural production. Table 1 also

Table 1: Socio-Economic distribution of respondents

\begin{tabular}{|c|c|c|}
\hline Variables & Frequency $(n=1750)$ & Percentage \\
\hline \multicolumn{3}{|l|}{ Age of the farmers (years) } \\
\hline$\leq 30$ & 234 & 13.4 \\
\hline $31-40$ & 463 & 26.4 \\
\hline $41-50$ & 669 & 38.3 \\
\hline $50-60$ & 255 & 14.5 \\
\hline$>60$ & 129 & 7.4 \\
\hline \multicolumn{3}{|l|}{ Educational status } \\
\hline No formal education & 392 & 22.4 \\
\hline Primary school & 431 & 24.6 \\
\hline Secondary school & 565 & 32.3 \\
\hline Post- secondary school & 362 & 20.7 \\
\hline \multicolumn{3}{|l|}{ Years of farming experience } \\
\hline$\leq 10$ & 409 & 23.4 \\
\hline $11-20$ & 497 & 28.4 \\
\hline $21-30$ & 475 & 27.1 \\
\hline $30-40$ & 286 & 16.4 \\
\hline$>40$ & 83 & 4.7 \\
\hline \multicolumn{3}{|l|}{ Gender } \\
\hline Male & 1056 & 60.3 \\
\hline Female & 694 & 39.7 \\
\hline \multicolumn{3}{|l|}{ Marital Status } \\
\hline Single & 139 & 7.9 \\
\hline Married & 1491 & 85.2 \\
\hline Divorced & 57 & 3.3 \\
\hline Widowed & 63 & 3.6 \\
\hline \multicolumn{3}{|l|}{ Household Size } \\
\hline$<5$ & 546 & 31.2 \\
\hline $6-10$ & 875 & 50 \\
\hline $10-15$ & 278 & 15.9 \\
\hline$>15$ & 51 & 2.9 \\
\hline
\end{tabular}

Source: Field data analysis, 2019 
revealed the gender status result which reveals $60.3 \%$ of the respondents are male while $39.7 \%$ are female farmers, it reveals from the table that male is actively involved in farming activities in the study area which tends to increase agricultural production because of their strength and energy. This also corroborate with Akintobi et al. [5] who implies that gender is a significant factor in agriculture because of its vital role in determining farming activities, and this could influence the adaptive capacity to employ various indigenous agricultural methods.

Table 1 further present the marital status of the respondents, $5.2 \%$ of the respondents are married, $7.9 \%$ were single, $3.3 \%$ are widowed while $3.6 \%$ of the farmers had divorced their partners. It reveals that most of the respondents still kept their marriage as a moral value of the rural communities while some farming households keeps their marriage as a means of combating food insecurity [8]. Table 1 further shows the household size of the farmers and it reveals the number of family members who are currently living in the same physical building with the head farmer and are dependent on the farmer for food and basic needs. The data reveals $31.2 \%$ of the farmers had a household of less than 5 persons, $50 \%$ of the respondents had household size between 6 persons to 10 persons, $15.9 \%$ of the respondents had a household between 11 and 15 persons, while only $2.9 \%$ of the respondents had household over 15 persons. These results imply that household sizes among small scale farmers are large.

\section{Level of Access to Labor Input in North Central States of Nigeria}

Table 2 revealed the analysis of variance result of small scale farmers' perception on access to labor input in North Central Nigeria, it test the hypothesis which state that small scale farmers do not perceive lack of access to human labor, the result $F(4,1745)=86.38, p=0.00$ indicated the small scale farmers perceived a lack of access to human labor for agricultural activities in the zone. Hence, the null hypothesis was rejected and alternative hypothesis is accepted. Which states that "Small scale farmers in North Central Nigeria perceive a lack of access to human labor".

The mean separation is indicated in Fig 1, this indicates the perceived level of access to human labor by farmers in each of the state.

Fig. 1 shows the Farmers' rating of access to labor input in each of the states. The result reveals that Niger state had mean response of 2.72 which ranked the highest, this is followed by Nasarawa state with an average mean of 2.51, Plateau state had a low mean of 2.32, Federal capital Abuja had a very low mean response of 2.01 while Kwara had the least mean response on rating of access to labor with a mean of 1.72. This result reveals that Niger state had the highest access to labor in North central Nigeria, this means that Niger state small scale farmers has good access to human labor on their farm compared to other states, while Kwara state showed the least labor accessible state. Implication of this result is that cost of agricultural production in these states might be capital intensive and many of the farmers would be hindered from producing at an optimum level. This result showed that majority of the north central states do not have good access to human labor on the farm this was corroborated by Osugiri et al. [[9] who stated that Labor contributed to the highest factor cost, This phenomenon was attributed by farmers to drift of the work force to urban centers for white collar jobs to the neglect of the agricultural sector. However, residents/inhabitants of the urban areas depend on the output (produce) of farmers in the neglected rural areas for sustenance. This has adversely affected price of food items leading to reduced standard of living for the people.

\section{Challenges of Small-Scale Farmers' Access to Human Labor Input}

Table 3 reveals the challenges faced by small scale farmers in accessing human labor for agricultural production, the result reveals that high cost of acquiring labor is the most experienced challenge encountered by the small-scale farmers in North Central Nigeria possessing 28\% of the total challenges experienced by small scale farmers in the study zone. $66 \%$ of Kwara state small scale farmers reveals that high cost of labor is their major challenge in accessing human labor for agricultural production, Nasarawa state farmers showed a $25.4 \%$ of Nasarawa state farmer reported that cost of labor is a major challenge, 24.9\% plateau state farmers also reveals that high cost of labor is a factor limiting access to human labor. However, Abuja and Niger state small scale farmers reveals high cost of acquiring labor is not a challenge with both states showing $16.9 \%$ and $7.1 \%$ respectively. This result reveals that labor per day cost in north central Nigeria is very high as small scale farmers who are barely surviving pay more for human labor and it has serious effect on their expense and profitability. This study correlate with the study of Issa et al. [10] who stated that high cost of labor is a key challenge experienced by small scale farmer in Nigeria. The result also revealed that lack of fund by the small-scale farmer to engage human labor on the farm is also a challenge they face in agricultural production as $21.43 \%$ of the respondents attested

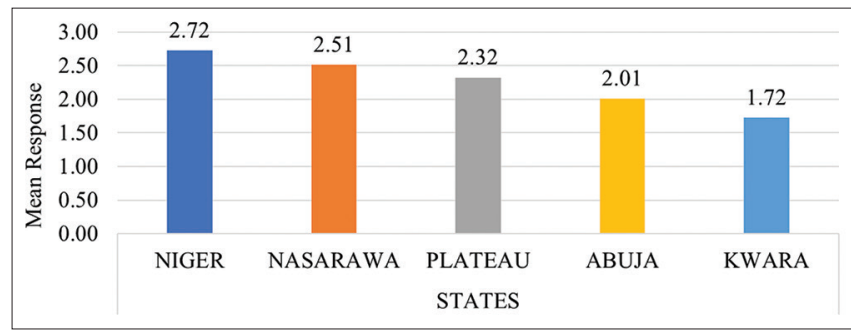

Figure 1: Farmers' rating of access to labor input in each of the states

Table 2: ANOVA results of small-scale farmers' perception on access to labor input

\begin{tabular}{lccccc}
\hline Sources of variation & Df & SS & MS & F-cal & $P$-value \\
\hline Access to Labor & 4 & 221.59 & 55.40 & 86.38 & .00 \\
Error (between subjects) & 1745 & 1119.18 & 0.64 & & .00 \\
Total & 1749 & 1340.77 & & & \\
\hline
\end{tabular}

Source: Field data analysis, 2020 
Table 3: Challenges to small-scale Farmers' access to Human labor in the north central zone

\begin{tabular}{|c|c|c|c|c|c|c|c|c|c|c|c|c|}
\hline \multirow{3}{*}{ Challenges } & \multicolumn{10}{|c|}{ States } & \multicolumn{2}{|c|}{ Pooled Data } \\
\hline & \multicolumn{2}{|c|}{ Plateau } & \multicolumn{2}{|c|}{ Niger } & \multicolumn{2}{|c|}{ Abuja } & \multicolumn{2}{|c|}{ Kwara } & \multicolumn{2}{|c|}{ Nasarawa } & & \\
\hline & Frq & $\%$ & Frq & $\%$ & Frq & $\%$ & Frq & $\%$ & Frq & $\%$ & Frq & $\%$ \\
\hline High cost of labor & 87 & 24.9 & 25 & 7.1 & 59 & 16.9 & 231 & 66 & 89 & 25.4 & 491 & 28.06 \\
\hline Lack of fund to engage labor & 93 & 26.9 & 111 & 31.7 & 66 & 18.9 & 4 & 1.1 & 101 & 28.9 & 375 & 21.43 \\
\hline Human Labor scarcity & 5 & 1.4 & 6 & 1.7 & 37 & 10.6 & 100 & 28.6 & 88 & 25.1 & 236 & 13.49 \\
\hline Inadequate credit facility & 76 & 21.7 & 0 & 0 & 51 & 14.6 & 8 & 2.3 & 30 & 8.6 & 165 & 9.43 \\
\hline Competitiveness of Preferred labor category & 13 & 3.7 & 37 & 10.6 & 95 & 27.1 & 1 & 0.3 & 11 & 3.1 & 157 & 8.97 \\
\hline Rural-Urban Migration & 53 & 15.1 & 23 & 6.6 & 29 & 8.3 & 4 & 1.1 & 18 & 5.1 & 127 & 7.26 \\
\hline Non-availability of preferred labor & 13 & 3.7 & 100 & 28.6 & 7 & 2.0 & 0.0 & 0.0 & 0.0 & 0.0 & 120 & 6.86 \\
\hline Unfavourable labor laws & 10 & 2.9 & 48 & 13.7 & 6 & 1.7 & 2 & 0.6 & 13 & 3.7 & 79 & 4.51 \\
\hline
\end{tabular}

Source: Field Survey 2020

to this claim. The result further indicated that $31.7 \%$ of the Niger state small scale farmers has lack of fund challenges in engaging human labor on their farm, $28.9 \%$ of Nasarawa state farmers reveals that lack of fund to engage labor is a factor that has hindered them in agricultural production, $26.9 \%$ of the plateaus state small scale farmers attested to the lack of fund challenge in engaging human labor for agricultural production while $18.9 \%$ and $1.1 \%$ scale farmers from federal capital Abuja and Kwara state respectively reveals lack of fund as a challenge in engaging human labor for agricultural activities. This result indicated that small scale farmers are incapacitated fund wise in order to engage human labor to improve agricultural production in North Central Nigeria, the result also reveals Kwara state small scale farmers do not perceive lack of fund as a challenge to engage human labor. This result support the report of Rapsomanikis [11] who stated that small scale farmers are not capacitated with financial opportunity and are unable to meet up with the cost of acquiring human labor which is crucial in any agricultural production process. International Fund for Agricultural Development [12] observed that one of the negative factors that militate against high productivity in small scale farming in Nigeria is vicious circle of low productivity and income, total shortage of cash and limited investment resulting into human labor input deficiencies.

The table also reveals human labor scarcity as one of the challenges small scale farmers experienced, $13.49 \%$ of the farmers in north central Nigeria attested to shortage of human labor as a challenge in access labor for agricultural production. $28.6 \%$ of Kwara state farmers reveals that scarcity of human labor is a challenge to accessing labor in the state, $25.1 \%$ of Nasarawa state farmers attested to shortage of human labor as a factor militating against accessing human labor, Only 10.6\% of abuja farmers revealed scarcity of human labor as a challenge while $1.7 \%$ and $1.4 \%$ of Niger and Plateau farmers respectively showed scarcity of labor as a challenge in accessing human labor for agricultural production in North Central Nigeria. This result reveals Scarcity of human labor is a challenge faced by small scale farmers in north central Nigeria, there is a decline in agricultural labor force in north central Nigeria as many of the workers has opted for less drudgery and service-oriented jobs. This assertion is supported by Lobeck [13] who reported that labor shortage has threatened export opportunities of agriculture, A report claimed farm labor shortage is costing billions of dollars across the world and it is expected to rise a trend that would place more agricultural businesses at risk and seriously impede the agricultural sector's growth potential [14].

Another report stressed that More than $40 \%$ of farmers in the past five years have been unable to obtain all the workers they needed for the production of their main crop, according to the survey, Of the total reporting shortages, it found about $70 \%$ or more indicating they have experienced more trouble hiring in 2017 and 2018 [15]. Another report showed that farm human labor shortage is worse than expected [16] 9.43\% North Central small scale farmers reported that Inadequate credit facility to help with funding to engage more labor is a factor militating against access to human labor, the table further reveals $21.7 \%$ of plateaus farmers reveals that lack of credit access is a challenge to fund human labor on the farm, $14.6 \%$ of the abuja farmers also reveals lack of credit facility is a factor militating against the access to human labor, $8.6 \%$ and $2.3 \%$ of small scale farmers from Nasarawa and Kwara states reveals lack of fund as a challenge in accessing labor. None of the small-scale farmers in Niger state see lack of credit facility as a challenge in accessing human labor in north central Nigeria. This result reveals that farmers in North central Nigeria would be able to have access to human labor if access to credit facility is made available. This study corroborate with the study of Mgbenka and Agwu [17] who stated Small-scale farmers' productivity and growth are hindered by limited access to credit facilities, agricultural credit encompasses all loans and advances granted borrowers to finance and service production activities relating to agriculture, fisheries and forestry and also for processing, marketing, storage and distribution of products resulting from these activities, if farmers are avail of loan provision they will improve production level thereby increasing the amount of labor engaged for those production.

Competitiveness of preferred labor category occurs when the demand for the available labor category needed for a particular agricultural production is in short supply which cost small scale farmers time and capital to acquire the said labor category, $8.97 \%$ of the respondents across the north central states reveals competitiveness of preferred labor category as challenges in accessing human labor, the result further reveals $27.1 \%$ of Federal capital Abuja farmers are experiencing competitiveness of preferred labor category while $10.6 \%$ of Niger state farmers 
attested to competitiveness of labor category as a challenge in accessing labor category. $3.7 \%$ and $3.1 \%$ of Plateau state and Nasarawa state feel the strain of competitiveness of preferred labor category in accessing human labor. While only a minute $0.3 \%$ from Kwara feels competitiveness of preferred labor category as a challenge. This above result indicates that there is a labor demand and supply strain due to the seasonality of agricultural production. According to Agwu et al. [18] who supported this claim reported that bush clearing, bush burning and gathering of stumps, mound making, planting, weeding and harvesting operations are male dominated activities, this means that bush clearing is an exclusive type of operation reserved for the male gender. While female category is mostly engaged in bush burning and stump collection, post-harvest processing activities are female dominated farming operations which means that when these activities are being carried out and with the scarcity of human labor already experienced the competition to get capable labor category deepens and cost small scale farmers more. Rural-urban exodus of agricultural worker is a challenge that has been felt by small scale farmers in North central Nigeria, $7.26 \%$ of the respondents assert that urban urban migration as hindered access to human labor, the result further reveals that $15.1 \%$ of plateau state farmer felt the exodus of agricultural workers to the urban centers has affected their access to labor for agricultural production. $8.3 \%$ of Abuja farmers supported the claim that rural exodus is a challenge, $6.6 \%$ and $5.1 \%$ of Niger and Nasarawa states farmers also claimed the challenges of urban exodus has affected their access to labor while a few $1.1 \%$ of farmers supported the claim.

This result indicates rural migration of youth and able-bodied agricultural workers from the rural to the urban centers in search of less drudgery non seasonality jobs in the service sector. This is in consonance with the study of Lawal and Okeowo [19] who stated that rural- urban exodus is one of the major reason why agricultural production is still low despite the vast resources that abound in Nigeria, they also identified that rural-urban migration as a key factor in labor force reduction with its consequent decline in productivity and output. Mgbakor et al. [20] also corroborate with the result of this research as they claimed among other factors responsible for the decline of agricultural production is the case of rural urban migration which involves the movement of people (especially the youth) from the rural areas to the urban centers in search of better living such as employment opportunities and conducive environment etc. since the youths, who are constitute the labor force in the rural area are actively involved in the rural urban exodus. Hence a shift in the labor force to the urban centers with the incessant movement of the youth to the urban centers a greater gap is created in the rural labor force hence the reduction in production level, increased cost of agricultural commodities and increased cost of production as will pay more for labor. Amrevurayire [21] research on effect of rural urban migration on agriculture revealed that Migration of young adults from the rural areas also placed a greater burden on the farmers. For farmers to cover the same area of land as when he had extra assistance, he must work much longer hours thus depriving him of some time for leisure or participation in various social activities. The trend of the movement of the rural people into the city has also militated against the agricultural development in the country. The stage of agricultural development in Nigeria is labor intensive, able-bodied men who should till the land have abandoned their role in the farms, and have engaged themselves in petty trading in the urban areas.

The farmers also noted non-availability of preferred labor category as a challenge in accessing labor for agricultural production, $6.86 \%$ of the small scale farmers claimed the above statement, the result further revealed that $28.6 \%$ of Niger state farmers claimed unavailability of preferred labor to engage on their farms, $3.7 \%$ of plateau state farmers and $2 \%$ of Abuja farmers claimed unavailability of preferred labor category as a challenge in accessing human labor on their farm. None of Kwara state and Nasarawa state farmer claim unavailability of human labor. This result reveals that there is availability of labor in north central Nigeria even though they are not enough in relation to demand hence the cost of acquisition is high for small scale farmers who are financially incapacitated. This study relates with the study of Prabakara et al. [22] who stated that there is an acute labor non-availability for agricultural works in most rural areas affecting consequently the productivity levels of almost all the crops grown in the area. He further warned that if this trend continues, the cropping pattern of the rural areas may even get a shift towards tree crops like cashew and coconut, which are comparatively less labor-intensive. The reasons identified for the labor unavailability include higher wages in other locally available jobs, seasonal nature of agricultural job and presumption of an agricultural job as a low-esteem one. Unfavorable labor law is the least of the challenge small scale farmers experienced in accessing human labor, $4.51 \%$ of the farmers claimed the laws guiding labor engagement has not favour them, based on this factor $13.7 \%$ of Niger state farmers claimed unfavorable labor laws has limited their access to labor, $3.7 \%$ of Nasarawa state farmers feel they are marginalized from having full access to labor due to the labor laws in the country, $2.9 \%$ and $1.7 \%$ of plateau and Abuja farmers blamed the labors laws for their limited access to labor while only $0.6 \%$ of Kwara farmers feel their limited access to labor is as a result of the impending labor laws. This shows that labor laws which guide and bind both farmers and agricultural workers do not really favour the farmers who do not always have access to adequate support structures to solve problems they encounter daily on their farms, this instance can be related to when the government increases minimum wage of workers in a country and farmers who do not have good financial support are coarsed to pay minimum wage to the farm workers this result into impoverishing the farmers as their farm produce are largely underpriced and the already high cost of labor will skyrocket and leaves the farmers with little or no income as cost of labor already takes up most of the income generated from their farm.

\section{CONCLUSION AND RECOMMENDATION}

The small-scale farmers perceive the lack of access to human labor as such labor scarcity is an ongoing challenge for the farmers as they already perceive lack of smooth access to human labor for agricultural activities which means there is an ongoing decline in the availability of agricultural labor. High cost of 
labor, lack of capital to engage labor and scarcity of labor are the major challenges experienced by the farmers. It is therefore recommended that farmers should be encouraged to organize themselves into cooperative societies as to be able to engage in share labor and have access to farm resources to improve labor use efficiency and productivity.

\section{REFERENCES}

1. Panwal, E. F., (2017). Farm Labor Problems of Small-Scale Farmers: A Case Study of Some Farming Communities in Plateau State Nigeria, Journal of Agriculture and Sustainability, 10(2), 187-197.

2. Nmadu, J.N., \& Akinola, A., (2015). Farm Labor Supply and Utilization for Food Crop Production in Nigeria. Istanbul, Turkey Proceedings of INTCESS15- $2^{\text {nd }}$ International Conference on Education and Social Sciences

3. Yeboah, F. K., \& Jayne, T. S., (2018). Africa's Evolving Employment Trends. The Journal of Development Studies, 54(5), 803-832.

4. Christiaensen, L., \& Palacios-Lopez, A., (2015). Are Youth Exiting Agriculture En-Masse? Paper presented at the 2016 Center for the Study of African Economies Conference, Oxford, UK.

5. Akintobi, O. S., Evinemi, C. A, \& Achagwa, S. M. (2018). Analysis of the Problems Associated with Cowpea Storage among Farmers in Kuje Area Council, Federal Capital Territory Abuja, Nigeria. FUDMA Journal of Agriculture and Agricultural Technology, 4(1), 91-98.

6. Bawa, D. B., Donye, A. O., \& Nuhu, H. S., (2010). Analysis of Involvement of Women in Seed Systems in Borno State, North-East Nigeria. Agriculture and Biology Journal of North America, 1(6), 1237-1242.

7. Apata, T. G., Samuel, K. D., \& Adeola, A. O., (2010). Analysis of Climate Change Perception and Adaptation among Arable Food Crop Farmers in South Western Nigeria. Paper presented at the conference of International Association of Agricultural Economics pp.2-9.

8. Aphunu, A., \& Nwabueze, G.O., (2012). Fish Farmer's Perception of Climate Change Impact on Fish Production in Delta State. Journal of Agricultural Extension, 2(16), 1-13.

9. Osugiri, I. I., Ugochukwu, A., Onyaguocha, S. U., Onyemauwa, C. S. \& Ben-Chendo, G. N., (2012). Population Dynamics, Labor and Small-Holder Farmers' Productivity in Southeast Nigeria Journal of Economics and Sustainable Development, 3(12), 95-101.

10. Issa, F. O., Kagbu, J. H., \& Abdulkadir, S. A., (2016). Analysis of socio- economic factors influencing farmers' adoption of improved maize production practices in ikara local Government Area of Kaduna State, Nigeria. Agrosearch, 16(2), 15-24.

11. Rapsomanikis, G., (2015). The Economic Lives of Smallholder Farmers. Food and Agriculture Organization of the United Nations Rome. http:// doi:10.13140/RG.2.1.3223.9440. 48pp.

12. IFAD (International Fund for Agricultural Development), (2009). Key elements for supporting the renewed focus on agricultural productivity and small-scale agricultural development in Nigeria. Annual Report. 94pp.

13. Lobeck, J., (2018). Labor Shortage Threatens Export Opportunities Retrieved on 15 th December 2019 from, https://www.farmprogress. $\mathrm{com} /$ vegetables/labor-shortage-threatens-export-opportunities.

14. Duvall, Z., (2019) Another Year of Labor Shortage. Retrieved on November $10^{\text {th }} 2019$ from, https://www.fb.org/viewpoints/anotheryear-of-farm-labor-shortages.

15. Daniels, J., (2019). California Farmers Increasingly Turning to Mechanization Due to Labor Shortages. Retrieved on September 2019 from, https://www.cnbc.com/2019/05/01/farmers-turning-tomechanization-due-to-labor-shortages-says-survey.html

16. Tasker, J., (2018). Farm Labor Shortage 'Worse Than Expected'. Retrieved on September 2019 from, https://www.fwi.co.uk/news/ eu-referendum/farm-labor-shortage-worse-expected.

17. Mgbenka, R. N., \& Agwu, A. E., (2011). Communication Platforms Existing Among Research, Extension and Farmers in Eastern Nigeria. Journal of Agricultural \& Food Information, 14(1), 242-258.

18. Agwu, N.M., Nwankwo, E. E. \& Anyanwu, C.I. (2013). Determinants of Agricultural Labor Participation Among Youths in Abia State, Nigeria International Journal of Food and Agricultural Economics, 2(1), 157-164.

19. Lawal, A.S., \& Okeowo, T. A., (2014). Effect of Rural Urban Migration on Labor Supply in Cocoa Production in Ondo East Local Government Area of Ondo State. International letters of Natural sciences, 1(18), 1-11.

20. Mgbakor, M. N., Uzendu P. O., \& Usifo I. J., (2014). Effect of Rura Urban Migration by Youth on Agricultural Labor in Aniocha South Loca Government area of Delta State, Nigeria. Quest Journal of Research in Agriculture and Animal Science Volume, 2(6), 14-22.

21. Amrevurayire, E.A., (2016). Consequences of Rural-Urban Migration on the Source Region of Ughievwen Clan Delta State Nigeria. European Journal of Geography 7(3), 42-57.

22. Prabakara, C., Devia, K. S., \& Selvamb, S., (2011). Labor Scarcity - Its Immensity and Impact on Agriculture. Agricultural Economics Research Review, 24(1), 373-380. 